No. Issue: $17 \mid$ Communication |pp. 119-126

\title{
America - China Trade War on Triangle Currency Shock
}

\author{
Arisyahidin Hs. ${ }^{1, *}$ \\ 1 Department of Management, Faculty of Economics, Islamic University of Kadiri; \\ * Correspondence
}

Received: 18 August 2019; Accepted: 26 August 2019; Published: 30 September 2019

\begin{abstract}
This paper is to analyze the impact of trade war United States - Republic of China on ASEAN currency shock with the subject are the triangle counties; Indonesia, Malaysia, and Singapore. By comparing currency of those 3 states, we resulted the different impact of trade war of US-China on each country. Foreign exchange of Indonesia Rupiah is more volatile than Malaysia and Singapore. It mean that influence of US-China trading war on currency shock is depend on the economics power of each countries in the international trading. Indonesia as an emerging country also became the alternative penetration target. Besides the difference of international transaction system on those countries, we realize that Indonesia is a big country, so that the volume of consumptive is exactly large of amount.
\end{abstract}

Keywords: Trading war; Currency Shock; Money Exchange

\section{Introduction}

Donald Trump as the elected president of America with a business and entrepreneur background, made changes domestic policy and the rules of international trading involvement. One of the goals of American economic policy is protectionism. Although largely caused technological changes, lack of adjustment, the uneven benefits of globalization and stagnant of middle wages, but the blamed is international free trade (Hicks and Devaraj 2015 and Autor, Dorn, and Hanson 2016).

Since the beginning of 2018, the multilateral trading system has been challenged by unilateral decisions by the United States (US) which raising import tariffs for certain trading partners, especially China, which has been stimulated by an increase in the country's trading deficit in recent years, especially with China. According to Comtrade (2018), in 2017, the US trading deficit with China increased to $\$ 363$ billion, recorded the highest bilateral trading deficit. This represented $42 \%$ of the total trade deficit of US $\$ 861$ billion.

The United States is the third largest producer of petroleum and the second largest natural gas producer in the world. The most powerful of economy and technology in the world with GDP per capita US \$ 19.39 trillion in 2017, which is a quarter of the world's nominal GDP and the highest in the world. While China has a per capita GDP of US \$ 12.24 trillion in 2017 under the United States (Pujayanti, 2018).

The implementation of political rhetoric into policies which more nationalist, protectionist, and densely populated is a political reality that must be confronted. Indonesia and Southeast Asian emerging countries have developed based on openness and structural reform increasingly and also integrated with East Asia, in terms of intra-regional investment and trading flows. In the case of Indonesia, nationalism and protectionism are not much related to the problem of inequality as in developed countries and have been embedded in Indonesia's political rhetoric and policy. Nationalism in Indonesia has political, economic, social and cultural roots. This is a term of the essence of conspiracy theories whish related to some beliefs that there is foreign exploitation, and preoccupation with national dignity (Aspinall, 2018). This has also colored political rhetoric, even though there is a positive view of globalization which depends on the economic situation (Rizal and Pangestu 2018). 
The development of technology and the process of liberalization of world trade often turn out to be the battlefield of developed country. Yet, the awareness of the needs and efficiency of each country, makes the trading between countries is a must. So that making balance of currencies between countries is one of the efforts to maintain economic stability.

Globalization has influences and impacts on various fields and sectors, where the national borders, geographical location are not as barrier to the flow of information, capital, goods and services. In such conditions the community must be prepared to accept various influences and their impacts. Therefore all entities must strive to maintain flexibility to adapt the changes.

The trade war of America with China is a major event that has the potential to affect the world economy. In international trade the announcement of a trade war certainly has consequences for value on the foreign exchange market. Thus event study is still interesting to do. This event study can also be used to test the information content of an event on the economic impact in the countries involved (Arisyahidin, 2012).

In the Capital Market, according to Tandelilin (2010) event studies are studies that examine the impact of information announcements on the price of securities. This study can be done by studying the market reaction to an event whose information is published as an announcement (Hartono, 2012).

An international economic crisis always has an impact on the currency and subsequently has the effect of transmission in the surrounding countries. The occurrence of the US-China trade war also naturally creates currency problems in the Asian region such as Singapore, Malaysia and Indonesia.

Ciuriak and Xiao (2018) analyze the effects of the US-China trade war and show the harmful effects of increasing protectionism in the US and China, especially in terms of international trade and welfare reduction. But in the developed countries, such as the European Union, or countries where are geographically close to the US (Canada and Mexico) generally do not have a sensitive direct impact (Rojas-Romagosa (2018). However, Kogid, Ching, and Jusoh (2009) according to the contagion theory show that no country in one region can fend off the effects of contagion from an economic crisis.

In Contagion Effect Theory has two interpretations: 1). Caused by interdependence relationships such as macroeconomic similarities and trade relations between countries, and 2). More emphasizes on investor behavior that caused from the asymmetric information, collective behavior and the loss of trust of the country's macro performance.

Detection of the effects of the economic crisis on the value of a currency can be seen in the Foreign Exchange market. Foreign currency is a currency that functions as a means of payment to international finance and economic transactions, and also has an official exchange rate record at the central bank (Gitman and Zutter, 2012).

This currency becomes a mechanism where people can transfer purchasing power between countries, obtain or provide credit for international trade transactions, and minimize the possibility of loss the exchange rate fluctuations due to differences in the currency values of each countries (Serfianto, 2013) and Ekanada (2017).

Currency is another payment instrument used to financing the international economic and financial transactions. Exchange rates/currencies could be determined including the system of: 1). Fixed exchange rates, 2). Floating exchange rates controlled; 3). Free Floating exchange rates, and 4). Zone-Target arrangement to maintain exchange rates in agreed zones (Sartono, 2012).

Sugeng (2010) explained the exchange rate can affect prices through; 1). Direct Pass through that the changes of exchange rates influence the price of imported goods and services (in the domestic currency) which is reflected in the import price index, and 2) Indirect Pass through that the changes in marketing orientation from domestic to international markets are driving export imports of the countries.

Foreign exchange rates theory begins with the concept of purchasing power parity originally introduced by Ricardo (1817). This theory was later developed by Swedish economist Cassel (1916). Basic of the theory is the comparison of the value of one currency with another currency is determined by the purchasing power of the money against goods and services in each country. 
In general, foreign exchange rates are the price of a country's currency in commodities (gold or silver). A country's currency exchange rate may occur depreciation or appreciation caused by economic problems (monetary phenomena) or non-economic problems, such as the absence of political certainty in a country. So that it can cause a decrease in public confidence in the exchange rate of the country's currency. Shocks in the value of a country's currency become sensitive because of its dependence on international trade, although there are international arbitration theories for the use of foreign exchange differences through risk-free profits (Madura, 2008), and also the theory of normal \& abnormal return (Hartono, 2012).

From the trading side, the escalation of the trade war will make it difficult for developing countries to encourage exports. On the other hand there is the potential to be targeted for market penetration of goods as a diversion to the export market. The decreasing in exports and the increasing in imports potentially have resulted a trade deficit. The two countries also threatened each other to bring this issue to the World Trade Organization. Trade wars caused by the economic policies of the two countries can have implications to the global economy, including in the Southeast Asia region (Malaysia, Singapore and Indonesia).

Only two superpowers make a trade war, but other countries will feel the effects. Trade tensions between the US and China will at least cause a deeper global economic slowdown. Global demand will also fall and the volume and price of goods traded globally at a low level. The economic slowdown in each country can be responded and maintain with more flexible fiscal and monetary policies with the aim of preventing recession and promoting economic growth. This monetary policy can be realized by lower interest rates. This condition is to encourage changes in the exchange rates of each country.

The purpose of this paper generally is to analyze the fluctuations of the currency exchange rates of Singapore, Malaysia and Indonesia after the trade war of United States with Republic of China.

\section{Methodology}

3 of Southeast Asian countries affected by the US-China trade war with different characteristics will analyzed in this paper;1) Indonesia as a developing country, 2) Singapore as a developed country, and 3) Malaysia as a developing country but relatively stable for the exchange rate against the US Dollar than Indonesia.

This simple research used the event studies method that observes the impact of information announcements of US-China trade war on the price of foreign exchange. Event studies generally relate to how quickly information coming into the market, and can be reflected in foreign exchange prices. This method used in this study is to analyze the reactions of Singapore, Malaysia and Indonesia currency exchange rate shocks due to the United States trade war with China. We will compare the condition the exchange rate around including before and after the trade war of US-China. The event window used in this study is 30 weeks, in which 30 weeks before the statement of US President Donald Trump increases import duty tariffs on imported goods from China and 30 weeks after the statement.

This study used secondary data in the form of average weekly exchange rates published by Investing.com. Then we analyzed with the comparison method that compares data for conclusions. This comparison of data, opinions, and others is to describe and understand the changes condition caused by economic event. Investing.com. is a financial market platform that provides real-time data, price quotes, financial tools, the latest news and analysis from 250 exchanges around the world with 44 international editions.

Investing.com is the top ranks of three global financial websites of the world (according to Similar Web and Alexa). Covering more than 300,000 financial instruments, Investing.com offers unlimited access to the latest financial market tools such as real-time quotes and notifications, custom portfolios, personal notifications, calendars, calculators, and financial insights, all of those data is free of charge. In addition to the global stock markets, Investing.com also covers crypto 
currencies, world indices, world currencies, commodities, bonds, mutual funds \& interest rates, futures and ETF Options.

\section{Results and Discussions}

The 2018 trade war of United States-China began after US President Donald Trump on March 22, 2018 announced an import duty tariff of US \$ 50 billion for Chinese goods based under Article 301 of the United States constitution 1974 about Trading. This is the rules which stated that there were practices unfair trade and theft of intellectual property. These two countries reciprocate tariffs on imported goods to their respective countries.

China did not want to be outdone by the US, which had asked American company to leave the bamboo curtain country and impose a counter duty rate for imported goods from the US. The Chinese government also imposed import duties on more than 128 US products, including crude oil, agricultural products such as soybeans, and small aircraft to China. China unmitigated will also charge tariffs for cars and spare parts from the US. China will impose tariffs on import duties on imported goods from the US with amount US \$ 75 billion, and also set an additional tariff of $10 \%$ of the provisions that have been in force for each imported item.

Table 1. Exchange rates per 1 USD

\begin{tabular}{|c|c|c|c|c|c|c|}
\hline \multirow{2}{*}{ Date } & \multicolumn{3}{|c|}{ 1 USD conversion } & \multicolumn{3}{c|}{ Currency Exchange Rates } \\
\cline { 2 - 7 } & IDR & MYR & SGD & IDR & MYR & SGD \\
\hline $03 / 06 / 2018$ & $13,930.00$ & 3.9885 & 1.3353 & 0.9399 & 0.9622 & 0.9685 \\
\hline $10 / 06 / 2018$ & $13,930.00$ & 3.9855 & 1.3509 & 0.9399 & 0.9615 & 0.9798 \\
\hline $17 / 06 / 2018$ & $14,080.00$ & 4.0025 & 1.3582 & 0.9501 & 0.9656 & 0.9851 \\
\hline $24 / 06 / 2018$ & $14,330.00$ & 4.0395 & 1.3628 & 0.9669 & 0.9746 & 0.9884 \\
\hline $01 / 07 / 2018$ & $14,370.00$ & 4.0400 & 1.3574 & 0.9697 & 0.9747 & 0.9845 \\
\hline $08 / 07 / 2018$ & $14,380.00$ & 4.0515 & 1.3657 & 0.9703 & 0.9774 & 0.9905 \\
\hline $15 / 07 / 2018$ & $14,480.00$ & 4.0615 & 1.3624 & 0.9771 & 0.9799 & 0.9881 \\
\hline $22 / 07 / 2018$ & $14,417.50$ & 4.0625 & 1.3619 & 0.9728 & 0.9801 & 0.9877 \\
\hline $29 / 07 / 2018$ & $14,492.50$ & 4.0825 & 1,3665 & 0.9779 & 0.9849 & 0.9911 \\
\hline $05 / 08 / 2018$ & $14,475.00$ & 4.0850 & 1.3734 & 0.9767 & 0.9855 & 0.9961 \\
\hline $12 / 08 / 2018$ & $14,610.00$ & 4.1065 & 1.3710 & 0.9858 & 0.9907 & 0.9943 \\
\hline $19 / 08 / 2018$ & $14,642.00$ & 4.1085 & 1.3650 & 0.9879 & 0.9912 & 0.9899 \\
\hline $26 / 08 / 2018$ & $14,730.00$ & 4.1095 & 1.3722 & 0.9939 & 0.9914 & 0.9952 \\
\hline $02 / 09 / 2018$ & $14,820.00$ & 4.1450 & 1.3788 & 1.0000 & 1.0000 & 1.0000 \\
\hline $09 / 09 / 2018$ & $14,805.00$ & 4.1385 & 1.3742 & 0.9989 & 0.9984 & 0.9967 \\
\hline $16 / 09 / 2018$ & $14,819.00$ & 4.1300 & 1.3642 & 0.9999 & 0.9964 & 0.9894 \\
\hline $23 / 09 / 2018$ & $14,901.50$ & 4.1385 & 1.3665 & 1.0055 & 0.9984 & 0.9911 \\
\hline $30 / 09 / 2018$ & $15,180.00$ & 4.1465 & 1.3828 & 1.0243 & 1.0004 & 1.0029 \\
\hline $07 / 10 / 2018$ & $15,205.00$ & 4.1545 & 1.3779 & 1.0259 & 1.0023 & 0.9993 \\
\hline $14 / 10 / 2018$ & $15,187.50$ & 4.1580 & 1.3777 & 1.0248 & 1.0031 & 0.9992 \\
\hline $21 / 10 / 2018$ & $15,216.50$ & 4.1750 & 1.3800 & 1.0268 & 1.0072 & 1.0009 \\
\hline $28 / 10 / 2018$ & $14,952.50$ & 4.1625 & 1.3749 & 1.0089 & 1.0042 & 0.9972 \\
\hline $04 / 11 / 2018$ & $14,685.00$ & 4.1795 & 1.3792 & 0.9909 & 1.0083 & 1.0029 \\
\hline $11 / 11 / 2018$ & $14,611.50$ & 4.1920 & 1.3723 & 0.9859 & 1.0113 & 0.9953 \\
\hline $18 / 11 / 2018$ & $14,540.00$ & 4.1940 & 1.3753 & 0.9811 & 1.0118 & 0.9975 \\
\hline $25 / 11 / 2018$ & $14,302.50$ & 4.1845 & 1.3721 & 0.9651 & 1.0090 & 0.9951 \\
\hline $02 / 12 / 2018$ & $14,470.00$ & 4.1660 & 1.3701 & 0.9764 & 1.0051 & 0.9936 \\
\hline $09 / 12 / 2018$ & $14,585.00$ & 4.1855 & 1.3769 & 0.9841 & 1.0098 & 0.9986 \\
\hline $16 / 12 / 2018$ & $14,555.00$ & 4.1810 & 1.3747 & 0.9821 & 1.0087 & 0.9970 \\
\hline $23 / 12 / 2018$ & $14,560.00$ & 4.1525 & 1.3665 & 0.9825 & 1.0018 & 0.9911 \\
\hline $5045: w w w$ & & & & & \\
\hline
\end{tabular}

Source: www.investing.com

On March 22, 2018 US President Donald Trump signed a memorandum referring to Article 301 of the 1974 Trade Act, and ordered the United States Trade Representative Office (USTR) to 
impose an import duty of US $\$ 50$ billion on Chinese goods. The proposed fee is a response to China's unfair trade practices for years, including theft of US intellectual property.

On April 2, the Chinese Ministry of Commerce imposed 128 duties on US products including pieces of aluminum, airplanes, cars, pork products and soybeans (which have a $25 \%$ tariff), fruits, nuts and steel pipes (15\%). USTR subsequently published a list of more than 1,300 Chinese imported goods worth $\$ 50$ billion in duties, including aircraft parts, batteries, flat screen televisions, medical equipment, satellites and weapons. The policy was responded by China with the imposing an additional $25 \%$ tariff for crude oil, small aircraft, cars, and soybeans which are the main US agricultural exports to China. On April 5, Trump instructed USTR to consider an additional $\$ 100$ billion in duties.

On July 6, 2018 US President Donald Trump imposed an import duty on Chinese goods worth $\$ 34$ billion, which then caused China imposed the similar rate on US products. In August 2017 America opened an official investigation into attacks on the intellectual property of America and its allies, and theft which makes loss of America around \$ 600 billion per year. Such duties are needed to protect national security and intellectual property of US businesses, and to help reduce the US trade deficit with China.

Two superpowers are involved at war, but other countries will feel the effects. The impact on the exchange rate on trade of 3 Southeast Asian currencies per US \$ 1 for 30 weeks after the USChina trade war statement is presented in table $\mathbf{1}$ and figure $\mathbf{1 .}$

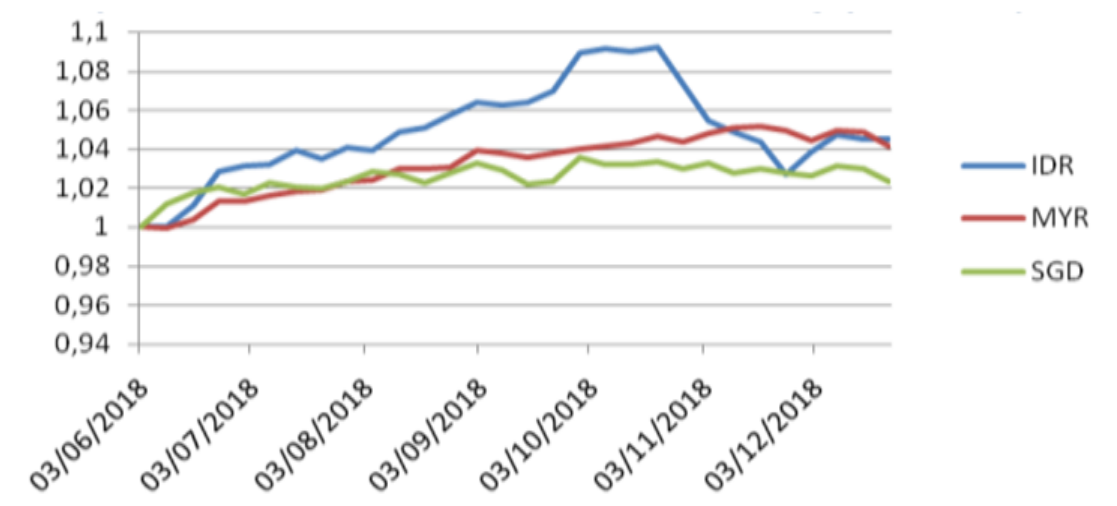

Fig. 1. Comparison of Currency Exchange Rates with USD between IDR, MYR, and SGD

The chart above (figure 1) shows that there was an increase in the currencies of the 3 indicator countries at the beginning of the announcement of the trade war, 1 June 2018. The Indonesian currency rose quite rapidly from the previous trade, while Malaysia and Singapore were more likely to be stable despite a decline. This is due to the pattern of Indonesian trade that applies due payment on almost all of its transactions, so the need for dollar payments will tend to rise and then cause rise the dollar prices, unlike in Singapore and Malaysia. Furthermore, the changes in the exchange rate of Indonesian currency (Rupiah) are presented in figure 2.

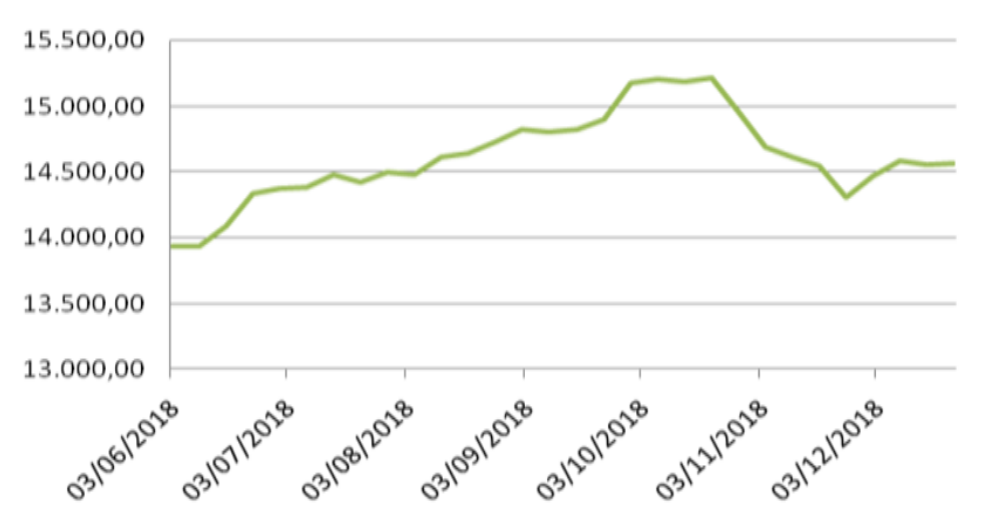

Fig. 2. Currency Exchange Rates for USD to IDR 
The chart above shows that Rupiah tends a significant change of almost close to 1,300 rupiah per US dollar. Whereas other currencies also follow the movement of the rupiah exchange rate. It is also caused of the role of China as the largest supplier and manufacturer who targeting the markets of emerging countries with small resources and developing countries.

The weakening of Rupiah on US dollar was triggered by the strengthening of the US dollar against all world currencies, which was also followed by an increase in yields or yields on US government bonds and world oil prices. On the other hand, the issue of the trade war between the US and China reheated after the US reached a new trade agreement with Canada and Mexico which signaled restrictions on goods from China.

The reaction or impact of the trade wars of each country varies depending on the power and the number of goods that enter the country. The impact on the Indonesian rupiah exchange rate due to the trade war. When we compared to the same period the previous year (2017) can be seen from table 2 and graph 3 as follows,

Table 2. IDR exchange rates on 30 weeks before the trade war US - China

\begin{tabular}{|c|c|c|c|}
\hline Year 2017 & USD to IDR & Year 2018 & USD to IDR \\
\hline $04 / 06 / 2017$ & $13,291.50$ & $03 / 06 / 2018$ & $13,930.00$ \\
\hline $11 / 06 / 2017$ & $13,297.50$ & $10 / 06 / 2018$ & $13,930.00$ \\
\hline $18 / 06 / 2017$ & $13,327.50$ & $17 / 06 / 2018$ & $14,080.00$ \\
\hline $25 / 06 / 2017$ & $13,327.50$ & $24 / 06 / 2018$ & $14,330.00$ \\
\hline $02 / 07 / 2017$ & $13,403.00$ & $01 / 07 / 2018$ & $14,370.00$ \\
\hline $09 / 07 / 2017$ & $13,338.50$ & $08 / 07 / 2018$ & $14,380.00$ \\
\hline $16 / 07 / 2017$ & $13,312.50$ & $15 / 07 / 2018$ & $14,480.00$ \\
\hline $23 / 07 / 2017$ & $13,326.50$ & $22 / 07 / 2018$ & $14,417.50$ \\
\hline $30 / 07 / 2017$ & $13,316.00$ & $29 / 07 / 2018$ & $14,492.50$ \\
\hline $06 / 08 / 2017$ & $13,357.50$ & $05 / 08 / 2018$ & $14,475.00$ \\
\hline $13 / 08 / 2017$ & $13,362.00$ & $12 / 08 / 2018$ & $14,610.00$ \\
\hline $20 / 08 / 2017$ & $13,345.50$ & $19 / 08 / 2018$ & $14,642.00$ \\
\hline $27 / 08 / 2017$ & $13,343.00$ & $26 / 08 / 2018$ & $14,730.00$ \\
\hline $03 / 09 / 2017$ & $13,204.00$ & $02 / 09 / 2018$ & $14,820.00$ \\
\hline $10 / 09 / 2017$ & $13,240.00$ & $09 / 09 / 2018$ & $14,805.00$ \\
\hline $17 / 09 / 2017$ & $13,312.50$ & $16 / 09 / 2018$ & $14,819.00$ \\
\hline $24 / 09 / 2017$ & $13,471.50$ & $23 / 09 / 2018$ & $14,901.50$ \\
\hline $01 / 10 / 2017$ & $13,504.00$ & $30 / 09 / 2018$ & $15,180.00$ \\
\hline $08 / 10 / 2017$ & $13,499.00$ & $07 / 10 / 2018$ & $15,205.00$ \\
\hline $15 / 10 / 2017$ & $13,518.50$ & $14 / 10 / 2018$ & $15,187.50$ \\
\hline $22 / 10 / 2017$ & $13,616.50$ & $21 / 10 / 2018$ & $15,216.50$ \\
\hline $29 / 10 / 2017$ & $13,497.50$ & $28 / 10 / 2018$ & $14,952.50$ \\
\hline $05 / 11 / 2017$ & $13,532.50$ & $04 / 11 / 2018$ & $14,685.00$ \\
\hline $12 / 11 / 2017$ & $13,527.50$ & $11 / 11 / 2018$ & $14,611.50$ \\
\hline $19 / 11 / 2017$ & $13,502.50$ & $18 / 11 / 2018$ & $14,540.00$ \\
\hline $26 / 11 / 2017$ & $13,526.00$ & $25 / 11 / 2018$ & $14,302.50$ \\
\hline $03 / 12 / 2017$ & $13,547.50$ & $02 / 12 / 2018$ & $14,470.00$ \\
\hline $10 / 12 / 2017$ & $13,578.50$ & $09 / 12 / 2018$ & $14,585.00$ \\
\hline $17 / 12 / 2017$ & $13,561.00$ & $16 / 12 / 2018$ & $14,555.00$ \\
\hline $24 / 12 / 2017$ & $13,567.50$ & $23 / 12 / 2018$ & $14,560.00$ \\
\hline $31 / 12 / 2017$ & $13,415.50$ & $30 / 12 / 2018$ & $14,270.00$ \\
\hline & & & \\
\hline
\end{tabular}

Source: www.investing.com 

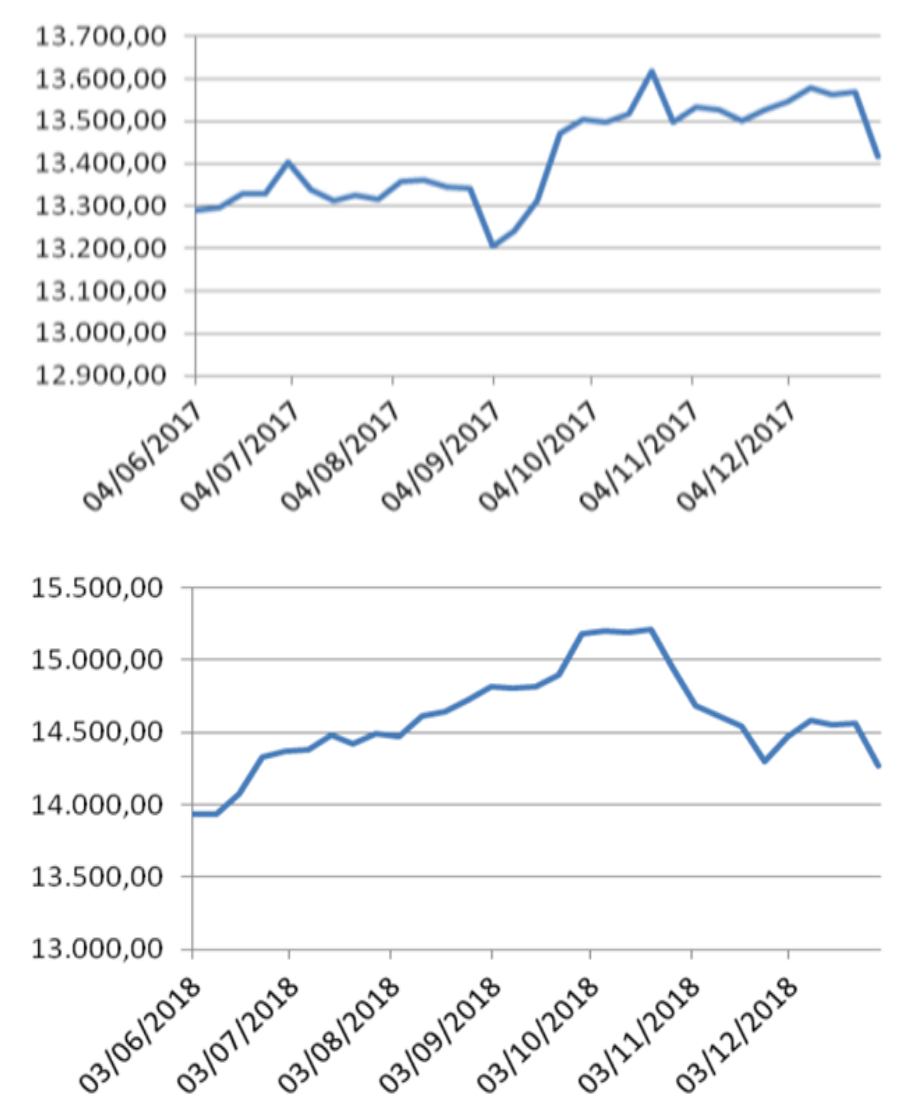

Fig. 3. Comparison between IDR exchange rates in 2017 (top), and 2018 (bottom)

Figure 3 shows the rupiah exchange rate in 2017 tends to be more stable compared to 2018 . In 2017 the same period of a trade war event showed the lowest exchange rate of Rp 13,204 and

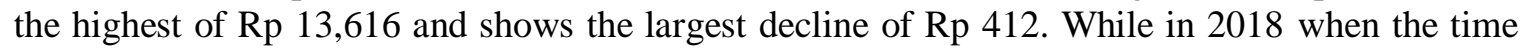
trade war event the lowest rupiah exchange rate of Rp 13,930 and the highest of Rp 15,216 (a

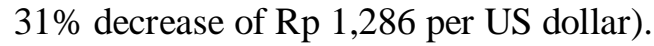

\section{Conclusions}

United States trade tensions with China on the entry tariffs of imported goods of each country have a significant impact on the exchange rates of Southeast Asian countries. The 3 indicators of countries affected by the trade war are Indonesia, Singapore and Malaysia. Of the three countries, the Indonesian Rupiah has the most volatile exchange rates against the US Dollar.

The impact of a trade war depends on economic independence and strength in international trade in each country. Not only fiscal policy, but also monetary policy has an important role to anticipate the exchange rate pressures due to the international trade war.

Indonesia as a big country becomes the target of Asian trade and the customs of shipping backs off on every transaction with US dollars. Whereas Singapore and Malaysia did not have much influence on this trade war because the consumptive value and purchase quantity tended to be less, also the transaction system was slightly different.

\section{Acknowledgement}

The author has no conflict of interest. 


\section{References}

Afrizal, 2008. Analisis Beberapa Faktor Yang Berpengaruh Pada Nilai Tukar Rupiah terhadap Dollar Amerika Serikat. Untan Press.

Arisyahidin Hs., 2012. Dampak Kebijakan Kenaikan Harga Bahan Bakar Minyak (BBM) terhadap Investasi Saham di Bursa Efek Indonesia (BEI). Revitalisasi, 1(2). September 2012.

Brigham, E.F. and L.C. Gapenski, Phillip R. Daves. 1999. Intermediate Financial Management, Sixth Edition. The Dryden Press. New York.

Hartono, J., 2010. Study Peristiwa: Menguji Reaksi Pasar Modal Akibat Suatu Peristiwa, Edisi Pertama. BPFE. Yogyakarta.

Hartono, J., 2012. Teori Portofolio Dan Analisis Investasi, Edisi ke-2, BPFE Yogyakarta.

Hartono, J., 2013. Pasar Efisien Secara Keputusan. Gramedia Pustaka Utama, Jakarta.

Hull, John C., 2007. Risk Management and Financial Institutions, 1st Edition. University of Toronto.

Madura, Jeff. 2006. Keuangan Perusahaan Internasional, Edisi 8 Buku 1. Jakarta: Salemba empat.

Prasojo, H.S.U. 2013. Reaksi Pasar Saham Terhadap Pengumuman Krisis Finansial Global (studi pada perusahaan pertambangan yang masuk dalam LQ45). Jurnal Ekonomi dan Bisnis.

Ralph, H. Folsom dkk, 1992. International Business Transaction. USA: West Publishing Co.

Rao, R. KS., 1994. Fundamental of Financial Management. MacMillan Publishing Company. New York.

Ross, and Jordan. 2008. International Corporate Finance. McGraw Hill Companies Inc, All Rights Reserved.

Sartono, Agus. 2012. Manajemen Keuangan Internasional. BPFE Yogyakarta.

Serfianto, R.DP. 2013. Pasar Uang dan Pasar Valas. PT Gramedia Pustaka Utama. Jakarta.

Shapiro, Allan C., Sheldon D. Balbirer, 2000. Modern Corporate Finance: A Multidiciplinary Approach To Value Creation. Prentice - Hall. Canada. Inc. Toronto.

Sugeng, dkk. 2010. Pengaruh Dinamika Penawaran Dan Permintaan Valas Terhadap Nilai Tukar Rupiah Dan Kinerja Perekonomian Indonesia. Buletin Ekonomi Moneter Perbankan Bank Indonesia.

Tandelilin, E. 2011. Analisis Investasi dan Manajemen Portofolio. BPFE. Yogyakarta. 